\title{
Service marketing triangle and GAP model in hospital industry
}

\author{
Rajesh K. Yadav ${ }^{1, *}$, Nishant Dabhade ${ }^{2, * *}$ \\ ${ }^{1}$ Associate Prof. \& Head, Department of Management, RKDF College of Engineering, \\ Bhopal (M.P.), India \\ ${ }^{2}$ Assistant Professor, Department of Management, RKDF College of Engineering, \\ Bhopal (M.P.), India \\ *,**E-mail address: drrajeshkyadav@yahoo.com ,nishant.dabhade.mgmt@gmail.com
}

\begin{abstract}
A service is any act or performance, one party can offer to another that is essentially intangible and does not result in the ownership of anything its production may or may not be tied to a physical product. Service includes all economic activities whose output is not a physical product or construction, consumed at the time it is produced and provides added value in forms (such as convenience, amusement, timeliness, comfort and health) that are essentially intangible and it concerns of its first purchaser. Service Marketing triangle shows three interlinked groups (customer, provider and the company) that work together to develop, promote and deliver service to the satisfaction of the customer. Service marketing involves three types of marketing: External Marketing, Internal Marketing and Interactive Marketing, while when it comes to GAP model than there are four potential gaps (Knowledge gap, Service design and standard gap, Service performance gap, communication gap) within the service organization. If we talk about importance of service marketing in the hospital industry so we come to know that break at any point whether it is in service marketing triangle or in GAP model can spoil relationship of hospital with the existing and potential customers.
\end{abstract}

Keywords: Service; Service design; Service delivery; marketing triangle etc.

\section{INTRODUCTION}

A service is any act or performance, one party can offer to another that is essentially intangible and does not result in the ownership of anything its production may or may not be tied to a physical product. Service includes all economic activities whose output is not a physical product or construction, consumed at the time it is produced and provides added value in forms (such as convenience, amusement, timeliness, comfort and health) that are essentially intangible and it concerns of its first purchaser. Service marketing occupies three types of marketing: External Marketing, Internal Marketing and Interactive Marketing. In external marketing efforts are made to set up its customers' expectations, make promises to customers regarding what is to be delivered, anything that communicates to the customer before service delivery etc. Internal marketing refers to the activities the firm must carry on to train, motivate, and reward its employees. Unless service employees are able and willing to deliver on the promises made, the firm will not be successful in keeping its promises and the 
services marketing triangle will collapse. And In interactive marketing the actual service takes place. The firm's employees interact directly with customers. It is having a positive link through external marketing. There are four potential gaps (Knowledge gap, Service design and standard gap, Service performance gap, communication gap) within the service organization that may lead to a final and most serious gap: The difference between what customers expected and what they perceived was delivered. Marketing mix includes basic 4P's of marketing that are product, price, place and promotion and when it comes to service marketing mix, it includes three additional P's that are People, Process and Physical evidence.

The marketers have to be more careful in selecting the right marketing mix strategy in case of marketing of services in hospitals to satisfy the customer requirements. That's why in this research I have tried to find out that at the time of delivering the services in hospitals how can we effectively use these three additional P's (People, Process and Physical evidence) of marketing and how can we fill the spaces of GAP model by using the appropriate techniques of service marketing when it comes to hospital industry. The Services Sector contributes the most to the Indian GDP. The Sector of Services in India has the biggest India has the biggest share in the country's GDP, it accounts for more than $50 \%$ contribution. The various sectors under the Services Sector in India are hospitals, trade, hotels, construction, transport, restaurant, communication and storage, social and personal services, community, insurance, financing, business services, and real estate.

\section{CHARACTERISTICS OF SERVICES COMPARED TO GOODS}

It is not only important to communicate the service to consumers (external communication) but also within the organization (internal communication) - the latter is also called "internal marketing"

\begin{tabular}{|c|c|c|}
\hline GOODS & SERVICES & RESULTING IMPLICATIONS \\
\hline Tangible & Intangible & $\begin{array}{l}\text { Services cannot be inventoried } \\
\text { - } \begin{array}{l}\text { Services cannot be readily } \\
\text { displayed } \\
\text { Services cannot be patented }\end{array}\end{array}$ \\
\hline Standardized & Heterogeneity & $\begin{array}{c}\text { Service quality depends on many } \\
\text { uncontrollable factors }\end{array}$ \\
\hline $\begin{array}{c}\text { Production separate } \\
\text { from consumption }\end{array}$ & $\begin{array}{c}\text { Simultaneous production } \\
\text { and consumption }\end{array}$ & $\begin{array}{c}\text { Customer participate in and affect the } \\
\text { transactions Decentralization may be } \\
\text { required }\end{array}$ \\
\hline Nonperishable & Perishable & Services cannot be resold or returned \\
\hline
\end{tabular}

In this research we are trying to describe marketing of services in the context of hospitality sector with the help of two important and burning issues that is service marketing triangle and GAP model. But before we move to the topic, first we describe below the successive growth of marketing in hospitality sector. 


\section{EVOLUTION OF MARKETING FROM PRODUCT TO SERVICES} sector.

In this section we will discuss the origin of marketing in connection with hospitality

\section{Stage 1: Product-Orientation Stage}

In the product oriented stage the motto was "Make all you can".

1. Demand exceeds available supply.

2. All that is made can be sold.

3. Focus is on engineering and generating output, not the customer.

4. Epitomized between late 1800s and early 1930s.

\section{Stage 2: Sales-orientation Stage}

In the sales oriented stage the motto was "Sell all you make".

1. Supply frequently exceeds demand.

2. Focus is on promotion and pricing; objective is to sell the entire inventory.

3. Hard-sell techniques create stereotype of pushy, annoying salesperson.

4. Epitomized between early 1930s and 1950s.

\section{Stage 3: Market-orientation Stage}

In the market oriented stage the motto was "Make what you can sell".

1. Variety in markets, variety in products.

2. Employs full marketing mix that is only $4 \mathrm{P}$ of marketing.

3. Focus is on customer needs and satisfaction; profitability over volume.

4. Most typical current orientation.

\section{Stage 4: Service Dominant Stage}

In the service dominant stage the motto is "Make it together with the customers".

1. Service industries gain more and more importance.

2. Ideas generated in the service field spread to other sectors.

3. "Intangible product features"

In the Service dominant stage the service marketing takes place in hospitality sector.

\section{SERVICE MARKETING TRIANGLE}

Service marketing triangle involves 3 types of marketing:

\subsection{External marketing}

4.2. Internal marketing

\subsection{Interactive marketing}

In short, below we are trying to define all three types of marketing in the case of hospitality sector.

4. 1. External Marketing means "Setting the Promise"

- Marketing to end-users that are your clients (patients).

- Involves pricing strategy, promotional activities, and all communication with customers.

- Performed to capture the attention of the market, and arouse interest in the service. 
From the study point of view, In External marketing hospitals should consider their clients as a marketer or promoter since better services in your hospitals induces customers to promote that hospital at least by word of mouth. Better services should be provided at low initial prices or price penetration strategy should be followed.

Price can be used as a promotional tool in the market. Apart from pricing the team of well qualified doctors and behavioral hospital staff contributes in promotional strategies. Once the awareness of your hospital spreads to the potential customers, automatically the footfall will be increased.

\section{2. Internal Marketing means "Enabling the Promise"}

- Marketing to employees that mean marketing of your well qualified doctor's team.

- Involves training, motivational, and teamwork programs, and all communication with all employees including doctors and other supporting staff of your hospital.

- Enable employees to perform the service effectively, and keep up the promise made to the customer.

From the study point of view, In Internal marketing hospitals have to enable their promise that they have made to its existing as well as potential customer.

Here a hospital can hire a renowned doctor and by the worth of his name they can promote their hospital. In this part all the employee of the organization gets the training for performing the prior made promise.

Training enable employee to perform their work efficiently and effectively.

\section{3. Interactive Marketing means "Delivering the promise"}

- This is real time marketing and known as moment of Truth and Service Encounter.

- This refers to the decisive moment of interaction between the front-office employees and customers, i.e. delivery of service.

- This step is of utmost importance, because if the employee falters at this level, all prior efforts made towards establishing a relationship with the customer, would be wasted and it creates negative brand image of your hospital.

From the study point of view, In Interactive marketing real service delivery takes place. This is the time when your employee gets in touch with potential customers.

This is the most critical and significant step when it comes to assess the quality of hospital services.

Hospital administration should be careful enough at this step because it shows the hospitality toward your customers and generate and create brand image in the eye of potential customers. 


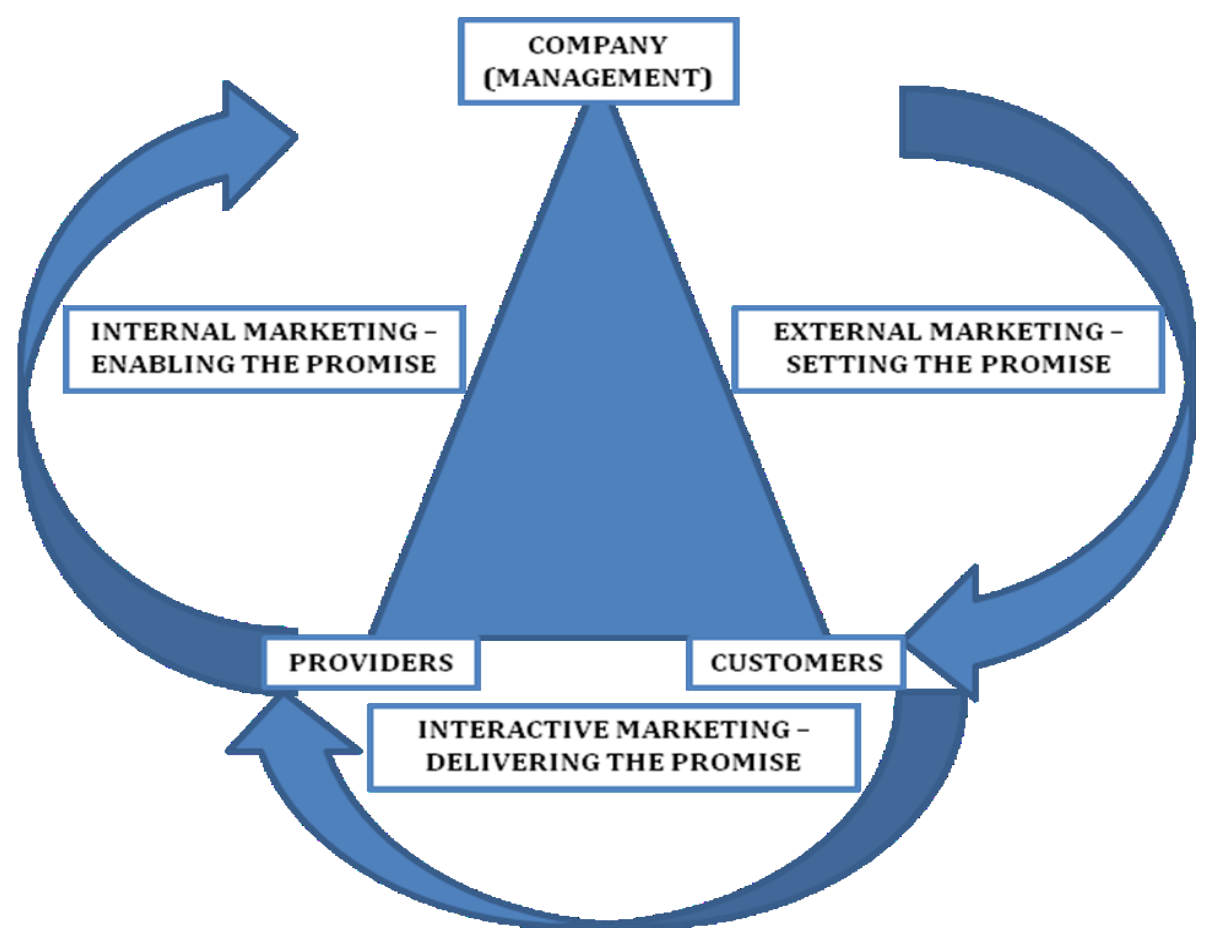

Figure 1. Service marketing triangle.

\section{ZONE OF TOLERANCE}

This is most critical time in hospital services since Services are heterogeneous i.e. performance of hospitals may vary across providers, across employees of same provider. The extent to which customer recognizes and are willing to accept this variation, is called Zone of tolerance. It is the range where customer does not particularly notice service performance of your hospitals. Hospital administration must try to perform better than the best during this time period. It generates customer loyalty, footfall, brand image and profit maximization.

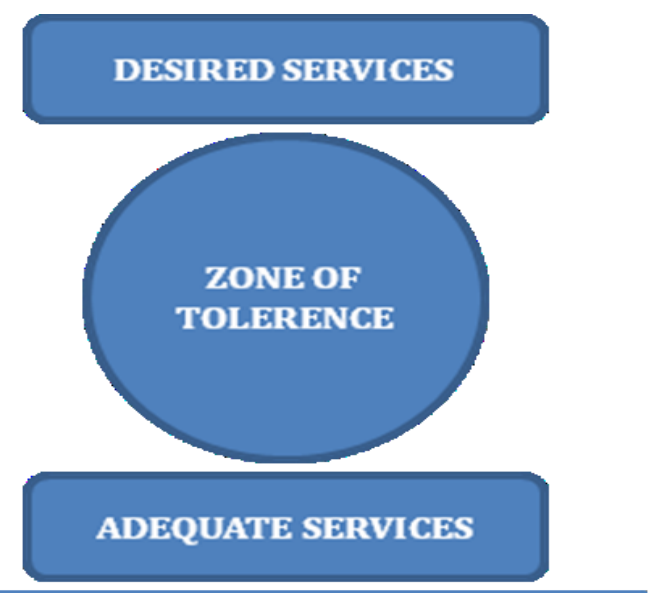

Figure 2. Zone of tolerance. 
In the case of service marketing triangle hospital sector must consider following point for the better facilitation of services.

- Make realistic accurate promises that reflect the service actually delivered rather than idealized version of service

- Ask contact people for feedback on the accuracy of promise made in advertising and selling

- Ensure service tangibles accurately reflect the type and level of service provided.

- Use market research to determine sources of derived customer expectation and their requirement

- Educate customers to understand their role and perform better.

- Identify influencers and opinion leaders for the service and concentrate marketing efforts on them.

\section{GAP MODEL}

Customer gap is the difference between Customer expectations and perceptions - the Service quality gap. Perceived service quality can be defined as the difference between consumers' expectation and Perceptions which eventually depends on the size and the Direction of the four gaps concerning the delivery of service quality on the company's side.

\section{Customer Gap = f (Gap 1, Gap 2, Gap 3, Gap 4, Gap 5)}

The magnitude and the direction of each gap will affect the Service quality. For instance, Gap 3 will be favorable if the Delivery of a service exceeds the standards of service required by the organization, and it will be unfavorable when the specifications of the service delivered are not met.

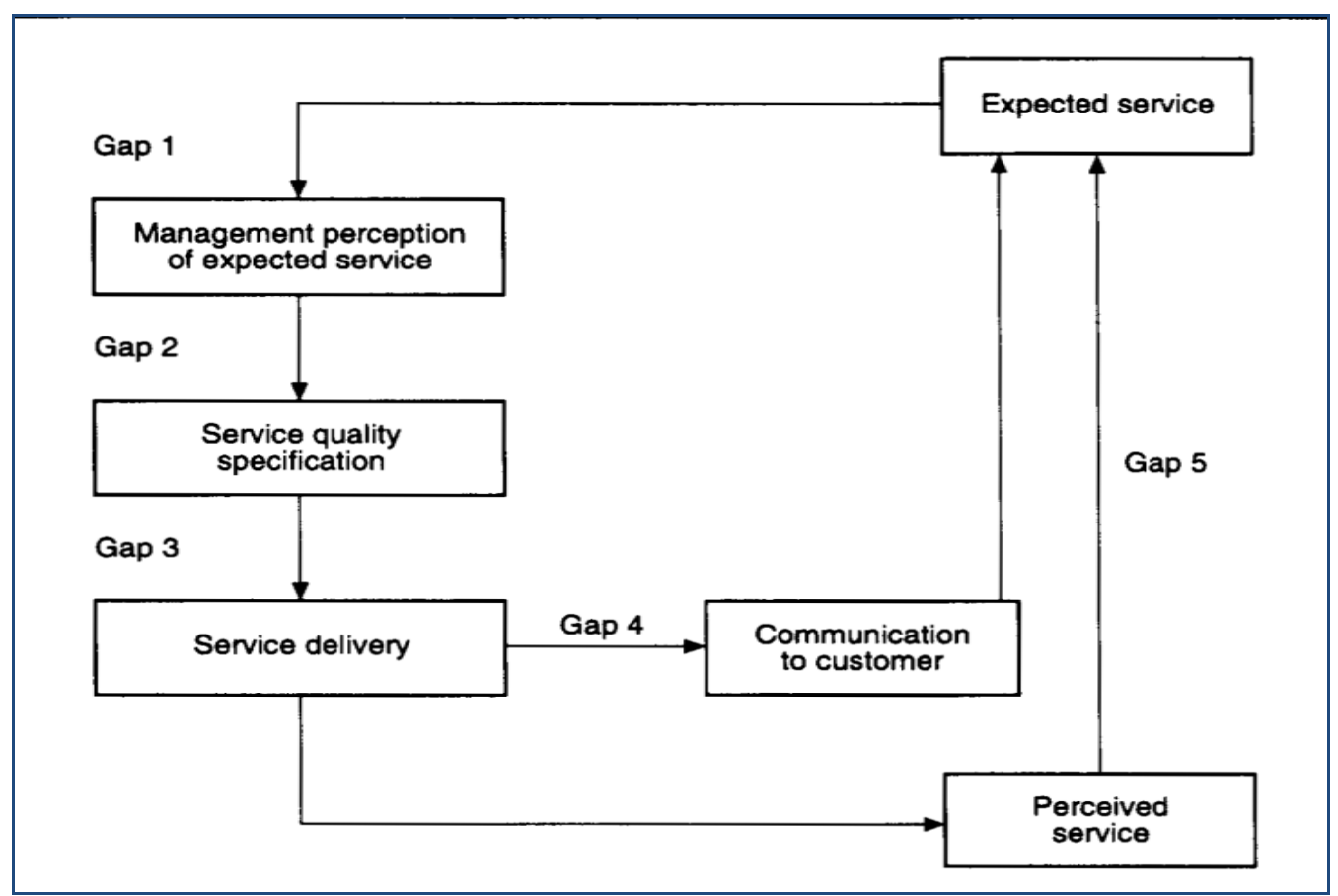

Figure 3. GAP model. 


\section{1. Provider Gap 1(The Knowledge Gap)}

In this gap hospitals generally don't know what customers expect. Following factors lead to this gap.

\section{Inadequate marketing research orientation}

○ Insufficient marketing research

- Research not focused on service quality

$\circ$ Inadequate use of market research

\section{Lack of upward communication}

○ Lack of interaction between management and customers

- Insufficient communication between contact employees and managers

- Too many layers between contact personnel and top management

\section{Insufficient relationship focus}

- Lack of market segmentation

- Focus on transactions rather than relationships

- Focus on new customers rather than relationship customers

\section{Inadequate service recovery}

○ Lack of encouragement to listen to customer complaints

- Failure to make amends when things go wrong

- No appropriate recovery mechanisms in place for service failures

\section{2. Provider Gap 2 (Service design and standards gap)}

In this gap hospitals generally do not select the right service designs and standards. Following factors lead to this gap.

\section{Poor service design}

- Unsystematic new service development process

- Vague, undefined service designs

- Failure to connect service design to service positioning.

\section{Absence of customer-driven standards}

- Lack of customer-driven service standards

- Absence of formal process for setting service quality goals.

\section{Inappropriate physical evidence and services cape}

○ Failure to develop tangibles in line with customer expectations

- Services cape design that does not meet customer and employee needs

- Inadequate maintenance and updating of the services cape

\section{3. Provider Gap 3 (The Service Performance Gap)}

In this gap hospitals generally do not deliver to service standards. Following factors lead to this gap.

\section{Deficiencies in human resource policies}

○ Ineffective recruitment

- Role ambiguity and role conflict

- Inappropriate evaluation and compensation systems

○ Lack of empowerment, perceived control, and teamwork 


\section{Customers who do not fulfill roles}

- Customers who lack knowledge of their roles and responsibilities

- Customers who negatively impact each other

\section{Problems with service intermediaries}

- Channel conflict over objectives and performance

- Difficulty controlling quality and consistency

- Tension between empowerment and control

\section{Failure to match supply and demand}

$\circ$ Failure to smooth peaks and valleys of demand

\section{4. Provider Gap 4 (The Communication Gap)}

In this gap hospitals generally do not match service performance that they have promised to their customers. Following factors lead to this gap.

\section{Lack of integrated services marketing communications}

○ Tendency to view each external communication as independent

- Absence of strong internal marketing program

\section{Ineffective management of customer expectations}

- Absence of customer expectation management through all forms of communication

$\circ$ Lack of adequate education for customers

\section{Overpromising}

○ Overpromising in advertising

- Overpromising in personal selling

○ Overpromising through physical evidence cues

\section{Inadequate horizontal communications}

$\circ$ Insufficient communication between sales and operations

- Insufficient communication between advertising and operations

$\circ$ Differences in policies and procedures across branches or units

\section{CONCLUSION}

Customers play a very vital role in successful delivery of service as customers are often present in the place where service is produced (Delivered). Customers alone can influence whether the delivered service is as per customer defined specifications. Other customers who are present in the Service can also influence the Service positively or negatively. Hence eventually to conclude our study we can say that in the hospitals marketing triangle plays an important role. We should make realistic accurate promises that reflect the service actually delivered rather than idealized version of service and Use market research to determine sources of derived customer expectation and their requirement.

Apart from that hospital administration tries to educate customers to understand their role and perform better. And the GAP model clearly determines the two different types of gaps in service marketing, namely the customer gap and the provider gaps. The latter is considered as internal gaps within hospitals. This model really views the services as a structured, integrated model which connects external customers to internal services between the different functions in a service organization. Hospital administration must think on 
reducing the gap between the customer expectation and customer perception. Because gap deduction will help to serve better to the customers and contributes in brand image, profit maximization and footfall of customers in the hospitals.

\section{References}

[1] Anderson E. W., Mittal V.S. (2000). "Strengthening the satisfaction-profit chain", Journal of Service Research, 3, 107-120.

[2] Bitner M. J., Booms B. H., Mohr L. A. (1994). "Critical service encounters: the employee's viewpoint", Journal of Marketing, 58, 95-106.

[3] Bitner M. J., Booms B. H., Tetreault M. S. (1990). "The service encounter: diagnosing Favorable and unfavorable incidents", Journal of Marketing, 54, 71-84.

[4] Bitner M. O. (1995). "Building service relationships: it's all about promises", Journal of the Academy of Marketing Science, 23, 246-251.

[5] Chhabra T. N., Grover S. K. (2009). "Marketing management", Dhanpat rai and co. private. Ltd.

[6] Chopra Anamica (2010). "Marketing management", Galgotia publishing company.

[7] Gronroos C. N. (2007). "Service Management and Marketing: Customer Management in Service Competition”, John Wiley \& Sons, Ltd, Chichester.

[8] Hall Englewood Cliffs N. J., Parasuraman A., Zeithaml V. A., Berry L. L. (1985). "A conceptual model of service quality and its implications for future research". Journal of Marketing, 49(4), 41-50.

[9] Heskett L., Jones T. O., Loveman G. W. et al. (1994). "Putting the service-profit chain to work". Harvard Business Review, 72, 164-174.

[10] Kothari C. R. (2004). "Research methodology-methods and techniques", new age international publishers, pp. 233-238.

[11] Kotler Philip, Keller Kevin Lane, Koshy Abraham, Jha Mithileshwer, (2009), "Marketing management", Pearson Education.

[12] Rust R. T., Moorman C., Dickson P. R. (2002). "Getting return on quality: revenue expansion, cost reduction, or both". Journal of Marketing, 66, 7-24. 